\title{
Tumor-associated E-cadherin mutations do not induce Wnt target gene expression, but affect E-cadherin repressors
}

\author{
Holger Laux ${ }^{1}$, Raju Tomer ${ }^{2}$, Michael T Mader ${ }^{3}$, Jan Smida ${ }^{1}$, Jan Budczies ${ }^{3}$, Roland Kappler ${ }^{4}$, \\ Heidi Hahn $^{4}$, Michaela Blöchinger ${ }^{1}$, Udo Schnitzbauer ${ }^{1}$, Friederike Eckardt-Schupp ${ }^{5}$, \\ Heinz Höfler ${ }^{1,6}$ and Karl-Friedrich Becker ${ }^{1}$
}

${ }^{1}$ Institute of Pathology, Technical University, Munich, Germany; ${ }^{2}$ Department of Biochemical Engineering
and Biotechnology, Indian Institute of Technology-Delhi, New Delhi, India; ${ }^{3}$ Institute for Bioinformatics,
GSF-National Research Center for Environment and Health, Neuherberg, Germany; ${ }^{4}$ Institute of Human
Genetics, University Goettingen, Goettingen, Germany; ${ }^{5}$ Institute of Molecular Radiation Biology,
GSF-National Research Center for Environment and Health, Neuherberg, Germany and ${ }^{6}$ Institute of
Pathology, GSF-National Research Center for Environment and Health, Neuherberg, Germany

\begin{abstract}
E-cadherin is a cell-cell adhesion molecule and tumor invasion suppressor gene that is frequently altered in human cancers. It interacts through its cytoplasmic domain with $\beta$-catenin which in turn interacts with the Wnt (wingless) signaling pathway. We have compared the effects of different tumor-derived E-cadherin variants with those of normal E-cadherin on Wnt signaling and on genes involved in epithelial mesenchymal transition. We established an in-house cDNA microarray composed of 1105 different, sequence verified cDNA probes corresponding to 899 unique genes that represent the majority of genes known to be involved in cadherindependent cell adhesion and signaling ('Adhesion/Signaling Array'). The expression signatures of E-cadherinnegative MDA-MB-435S cancer cells transfected with E-cadherin variants (in frame deletions of exon 8 or 9, D8 or D9, respectively, or a point mutation in exon 8 (D370A)) were compared to that of wild-type E-cadherin (WT) transfected cells. From the differentially expressed genes, we selected 38 that we subsequently analyzed by quantitative real-time RT-PCR and/or Northern Blot. A total of $92 \%$ of these were confirmed as differentially expressed. Most of these genes encode proteins of the cytoskeleton, cadherins/integrins, oncogenes and matrix metalloproteases. No significant expression differences of genes downstream of the Wnt-pathway were found, except in E-cadherin D8 transfected cells where upregulation of three Tcf/Lef-transcribed genes was seen. One possible reason for the lack of expression differences of the Tcf/Lef-regulated genes is upregulation of SFRP1 and SFRP3; both of which are competitive inhibitors of the Wnt proteins. Interestingly, known E-cadherin transcriptional repressors, such as SLUG (SNAI2), SIP1 (ZEB2), TWIST1, SNAIL (SNAI1) and ZEB1 (TCF8), but not E12/E47 (TCF3), had a lack of upregulation in cells expressing mutated E-cadherin compared to WT. In conclusion, E-cadherin mutations have no influence on expression of genes involved in Wnt-signaling, but they may promote their own expression by blocking upregulation of E-cadherin repressors.

Laboratory Investigation (2004) 84, 1372-1386, advance online publication, 16 August 2004; doi:10.1038/labinvest.3700158
\end{abstract}

Keywords: cDNA array; $\beta$-catenin; cadherin; E-cadherin repressors; microarray; Wnt pathway; epithelialmesenchymal transitions

Cadherins are cell-to-cell adhesion molecules that play a critical role in the establishment of adherenstype junctions by mediating calcium-dependent cellular interactions. ${ }^{1}$ Typical cadherins, such as E-cadherin or N-cadherin, are composed of three

Correspondence: Dr K-F Becker, PhD, Institute of Pathology, Technical University, Trogerstrasse 18, Munich 81675, Germany. E-mail: kf.becker@lrz.tu-muenchen.de

Received 4 March 2004; revised 11 June 2004; accepted 17 June 2004; published online 16 August 2004 domains: (a) an extracellular part mediating homophilic cadherin-cadherin interactions, (b) a transmembrane domain, and (c) a highly conserved cytoplasmic domain that links the cell adhesion protein complex to the cytoskeleton via $\alpha$ - and $\beta$-catenin. ${ }^{1-3}$ Besides its function in the cadherin cell adhesion complex, $\beta$-catenin also plays a role in the wingless (Wnt) signaling pathway. ${ }^{4-6}$ The Wnt proteins form a highly conserved, multimember ligand family. In vertebrates, Wnt signaling is involved in organ development and cellular 
proliferation, morphology and motility. ${ }^{7-9}$ Secreted Wnts bind to receptors of the Frizzled family located on the cell surface. ${ }^{10}$ Frizzled, in turn, activates the cytoplasmatic protein DVL (Dishevelled). The function of DVL is to inhibit the activity of glycogen synthase kinase (GSK-3 $\beta$ ). ${ }^{11}$ Otherwise, free $\beta$-catenin is rapidly phosphorylated by a complex consisting of GSK- $3 \beta,{ }^{12}$ adenomatous polyposis coli (APC) protein $^{13-15}$ and axin. ${ }^{16-19}$ Phosphorylated $\beta$-catenin is then target for degradation by the ubiquitin-proteasome pathway. ${ }^{20-22}$ Unphosphorylated $\beta$-catenin can translocate into the nucleus where it binds to members of the Tcf/Lef (transcription factors of the T-cell-specific and lymphoid enhancer-specific group) family., ${ }^{5,23-25}$ $\beta$-Catenin together with Tcf/Lef modulates transcription of target genes, such as TCF itself and the oncogenes CCND1 (cyclin D1) and MYC $(\mathrm{c}-\mathrm{myc})^{26,27}$ Misregulation of $\beta$-catenin is an important event in the development of several malignancies such as colon cancer, melanoma, hepatocellular carcinoma, ovarian cancer, endometrial cancer, medulloblastoma, pilomatricomas and prostate cancer.

Besides misregulation of $\beta$-catenin in tumor cells, it has long been known that malfunction of $\mathrm{E}$ cadherin allows tumor cells to invade the surrounding tissues. ${ }^{28}$ E-cadherin expression is also often reduced or absent in many epithelial cancers, including gastric and breast cancer. ${ }^{29-31}$ Downregulation of E-cadherin during tumor progression can be accomplished by various mechanisms, for example, transcriptional downregulation, ${ }^{32}$ mutation, ${ }^{31,33}$ and methylation. ${ }^{34}$ One example for E-cadherin repression is transcriptional downregulation by factors like SLUG, TWIST, SIP1, SNAIL, E12/E47 and ZEB1. ${ }^{35,36}$ The transcription factors SNAIL, SNAI3, E12/E47, ZEB1 and SIP1 bind to E-box elements at the proximal promoter site of E-cadherin leading to transcriptional inactivation of E-cadherin. The E-cadherin downregulation plays an important role in epithelial-mesenchymal transition (EMT) where epithelial cell subpopulations actively downregulate cell-cell adhesion systems during embryogenesis. They leave their 'local neighborhood' to move into new microenvironments where they differentiate into distinct cell types. This occurs, for example, during gastrulation and neural crest cell migration. ${ }^{37}$ SNAIL, for example, has now been firmly established as a repressor of E-cadherin in different murine and human carcinoma and melanoma cell lines, tumors $^{38-44}$ and in early development of Drosophila and mouse. ${ }^{35,45,46}$ The role of SLUG, another member of the SNAIL superfamily, ${ }^{35,47}$ as a potential E-cadherin repressor has been confirmed recently. ${ }^{48}$ It is expressed in EMT regions in both chick and Xenopus embryos. ${ }^{49-52}$ SIP1 (SMAD interacting protein 1) downregulates mammalian E-cadherin transcription via binding to both conserved E2 boxes of the minimal E-cadherin promoter. SIP1 and SNAIL bind to partly overlapping promoter sequences and showed similar downregulating effects. ${ }^{53}$ TWIST is an activator of N-cadherin during Drosophila embryogenesis, ${ }^{45}$ acts as a transcription factor and is also known to trigger EMT mechanisms. TWIST is possibly involved in EMT by repressing E-cadherin and initiation of $\mathrm{N}$-cadherin expression.

Correlation between P27KIP1 (CDKN1B) and E-cadherin were described in contact-dependent growth inhibition ${ }^{54}$ and may also play a role in EMT. Thus, it is important to gain knowledge about the cadherin-dependent expression profiles in tumor cells and nontumorous cells. In addition, cadherin-dependent changes in gene expression with regard to the Wnt pathway have been controversially discussed in the literature..$^{55,56}$ In the present work, we describe the establishment of an 'Adhesion/Signaling Array' and investigated thereby the effects of different E-cadherin variants on gene expression focusing on genes involved in Wnt signaling and E-cadherin repressors.

\section{Materials and methods}

\section{Cell Culture and RNA Preparation}

The human MDA-MB-435S cell line (ATCC, Rockville, MD, USA) was transfected with wild type E-cadherin (WT), E-cadherin lacking exon 9 (D9) and E-cadherin with a deletion (D8) or a point mutation in exon 8 (D370A) as described previously. ${ }^{57}$ The promoter used in these transfec tions was the $\beta$-actin promotor from chicken (not from human). The MDA-MB-435S cell line was supposed to be derived from a mammary carcinoma, but a recent paper suggested an origin from a melanoma. ${ }^{58}$ From three clones established and characterized for each variant, one representative clone was selected. The cells were cultured in Dulbecco's modified Eagle medium (DMEM) containing $4.5 \mathrm{~g} / \mathrm{l}$ glucose and supplemented with $10 \%(\mathrm{v} / \mathrm{v})$ fetal calf serum (PAN-Systems, Nuernberg, Germany) and penicillin-streptomycin $(50 \mathrm{IU} / \mathrm{ml}$ and $50 \mu \mathrm{g} / \mathrm{ml}$ (Invitrogen, Karlsruhe, Germany) in $150 \mathrm{~mm} \times 20 \mathrm{~mm}$ cell culture dishes at $37^{\circ} \mathrm{C}$ under $5 \% \quad \mathrm{CO}_{2}$ in humidified air. The transfected cells were cultivated with an additional supplement of $600 \mu \mathrm{g} / \mathrm{ml}$ geniticin (Invitrogen, Karlsruhe, Germany). The initial platings were $1.5 \times 10^{6}$ cells for the untransfected and E-cadherin negative cells and $2.0 \times 10^{6}$ cells for the transfected cells. The cultivation period lasted for 2 days with a final cell density of $80 \%$ (which corresponds to $1.6 \times 10^{7}$ cells). A large pool of total RNA was isolated with Trizol reagent (Invitrogen, Karlsruhe, Germany) according to the manufacturer's instructions and was used for all measurements. 


\section{Microarray Production}

The 'Adhesion/Signaling Arrays' were composed of 1105 complementary DNAs (cDNAs) coding for 899 unique human genes. Human Cot-1-DNA, poly $\mathrm{d}(\mathrm{A})_{40-60}$, salmon sperm, Arabidopsis spikes and housekeeping genes (a total of 47 sequences) were added as control sequences. All probes were spotted in duplicate. Therefore, our chip consists of 2304 spots. A complete list with all genes is available as supplementary table: http://telepath.gsf.de/pathol/ arrays.html.

Probes consisted of PCR amplified cDNAs from target genes (I.M.A.G.E. clones, obtained from RZPD, Berlin, Germany) and are typically located in the $3^{\prime}$-noncoding region. All clones were characterized and verified by $5^{\prime}$ and $3^{\prime}$ sequencing using standard techniques. The PCR products are between 500 and $1000 \mathrm{bp}$ in length and have a minimal concentration of $375 \mathrm{ng} / \mu \mathrm{l}$ in the spotting solution. Genes and the suitable clones were selected from both public databases and previously published reports. All bacterial clones were cultured in LB-medium ( $50 \mu \mathrm{g} / \mathrm{ml}$ ampicilin) at $37^{\circ} \mathrm{C}$ for $16 \mathrm{~h}$. The probes were amplified in $200 \mu \mathrm{l}$ PCR reactions (universal primer fw: GTT TTC CCA GTC ACG ACG TTG and universal primer rev: TGA GCG GAT AAC AAT TTC ACA CAG) in 96-well plates and purified by MultiScreen ${ }^{\mathbb{R}}$-PCR Filter Plate (Millipore, Schwalbach, Germany). The expected length of the PCR products and the absence of contaminations were confirmed by agarose gel electrophoresis; the DNA concentration was measured photo-optically. Before spotting, the PCR products were dried and dissolved in $20 \mu \mathrm{l}$ of a $\mathrm{H}_{2} \mathrm{O}$ /DMSO (1:1) mix.

The PCR products were printed in duplicate with an Affymetrix 417 arrayer (Affymetrix, Santa Clara, USA) onto super aldehyde slides (Arrayit, Sunnyvale, USA). After printing, the slides were placed at room temperature for no longer than 1 week and subsequently stored in an argon atmosphere.

\section{Probe Labeling and cDNA Microarray Hybridization}

We used two different labeling methods:

(1) Indirect labeling: Total RNA was reverse transcribed using aminoallyl labeled dUTPs. The Cy3 and Cy5 (Amersham, Freiburg, Germany) coupling reactions were performed with the FairPlay $^{\mathrm{TM}}$ microarray labeling kit (Stratagene Europe, Amsterdam, Netherlands). Each reaction was supplemented with $10 \mu \mathrm{g}$ human Cot-1-DNA, $8 \mu \mathrm{g}$ poly $\mathrm{d}(\mathrm{A})_{40-60}$ and $1 \mu \mathrm{l}$ of $5 \mu \mathrm{g} / \mu \mathrm{l}$ yeast tRNA. Cy3- and Cy5-coupled cDNAs were pooled and dissolved in $3 \times$ SSC and $0.25 \%$ SDS. This cDNA mix was heated to $99^{\circ} \mathrm{C}$ for $2 \mathrm{~min}$ and then cooled to $45^{\circ} \mathrm{C}$.

(2) Direct labeling: Isolated total RNAs were labeled by reverse transcription in parallel with Cy3- and Cy5-dCTPs (Amersham, Freiburg, Germany) and purified using the LabelStar kit (Qiagen,
Hilden, Germany). For each competitive hybridization experiment cDNAs labeled with Cy3 and Cy5 (ie experiment and control) were pooled, supplemented with $10 \mu \mathrm{g}$ human Cot-1-DNA, $8 \mu \mathrm{g}$ poly $\mathrm{d}(\mathrm{A})_{40-60}$ and $1 \mu \mathrm{l}$ of $5 \mu \mathrm{g} / \mu \mathrm{l}$ yeast tRNA and dried. Immediately before usage the evaporated mix was dissolved in $20 \mu$ l hybridization mix containing $50 \%$ formamid and $2 \times \mathrm{SSC}$ for $30 \mathrm{~min}$ at $60^{\circ} \mathrm{C}$ and denatured at $95^{\circ} \mathrm{C}$ for $5 \mathrm{~min}$.

The slides were washed twice for 2 min in $0.2 \%$ SDS solution, twice for 2 min in $\mathrm{H}_{2} \mathrm{O}$ and transferred into boiling water for another $2 \mathrm{~min}$. To block unspecific binding, the slide surface was subsequently treated in a mix of $0.65 \mathrm{~g}$ of $\mathrm{NaBH} 4$ dissolved in $200 \mathrm{ml}$ of $2 \times$ PBS and $65 \mathrm{ml}$ of ethanol for $5 \mathrm{~min}$, washed three times in $0.2 \%$ SDS and two times with $\mathrm{H}_{2} \mathrm{O}$ for $1 \mathrm{~min}$. The prehybridization was performed for $1 \mathrm{~h}$ in buffer containing $6 \times$ SSC, $0.5 \%$ SDS and $1 \%$ BSA at $42^{\circ} \mathrm{C}$, washed with $\mathrm{H}_{2} \mathrm{O}$ and dried.

The denatured Cy3/Cy5-labeled cDNA probes were competitively hybridized on a prehybridized microarray slide at $42^{\circ} \mathrm{C}$ for $16 \mathrm{~h}$ in a humidified chamber. The probed arrays were washed in a mix of $0.5 \%$ SSC and $0.01 \%$ SDS for $5 \mathrm{~min}$, in $0.06 \%$ SSC and $0.01 \%$ SDS for another $5 \mathrm{~min}$ and subsequently for $2 \mathrm{~min}$ in $0.06 \%$ SSC and dried. Laser scanning of the slides was accomplished by Affymetrix 418 scanner (Affymetrix, Santa Clara, USA).

\section{Image Processing}

Image analysis, spot finding and manual grid adjustment were performed with the Array-Pro software (Media Cybernetics, Silver Spring, MD, USA). For further data processing, we used the mean signal (threshold segmentation) of each spot and subtracted the mean signal of the local background. Defective cDNA spots (irregular geometry, scratched or dust particles) were flagged and imputed for further analysis (see below).

\section{Statistical Analysis}

The statistical analysis was implemented and conducted in the statistical computing environment R. ${ }^{59}$

\section{Quality Control}

In order to control reproducibility of replicated spots, we have estimated the relative errors of expression levels by the difference of two expression values divided by their mean. The resulting distributions were visualized as histograms and used to control the quality of both single arrays and series of replicated hybridizations. Interslide reproducibility was checked by control hybridizations, that is, RNA from one cell line was compared to RNA from that same cell line (eg WT vs WT) and analysis of the corresponding variances. 


\section{Normalization}

Mean expression levels were corrected by the mean local background. Flagged spots (see image segmentation) were set to NA. The log-transformation was computed for each microarray separately. The vectors of the four microarrays for each transfected line were combined to a matrix consisting of 2304 measurements (each probe spotted twice) over four replicates. Missing values in this matrix ('NA') were imputed with the Transcan algorithm. ${ }^{60}$ A nonlinear normalization was performed microarraywise (intraslide normalization) with a method based on the Loess smoother, ${ }^{61,62}$ followed by 'median absolute deviation' scale normalization. Ratios (ie differences of logscale values using the wild type-transfected MDA cell line as reference) were calculated prior to linear scaling between slides (interslide normalization).

\section{Tests for Differentially Expressed Genes}

On-chip replicates were treated as independent measurements. Differentially expressed genes were selected by two-sided one-sample Welch $t$-tests and/ or Wilcoxon rank tests. The $P$-values were adjusted according to the Benjamini-Yekutieli procedure for control of the false discovery rate. ${ }^{63}$ Adjusted $P$-values smaller than 0.05 were considered to be significant.

\section{Quantitative Real-Time RT-PCR}

Amounts of $2 \mu \mathrm{g}$ of total RNA were used for cDNA synthesis using the Superscript 2 reagents (Invitrogen, Karlsruhe, Germany) with oligo(dT)12-18 primers. Assay-on-demand (predesigned primer and probe sets) (Applied biosystem, Foster City, CA, USA) was applied for quantitative real time PCRreactions according to the procedure described by the manufacturer. Glyceraldehyde-3-phosphate dehydrogenase (GAPD) was used as calibrator.

\section{Northern Blot Analysis}

Amounts of $10 \mu \mathrm{g}$ of total RNA were electrophoretically separated on a $1 \%$ denaturing formaldehyde agarose gel, transferred onto a nylon membrane, and hybridized with radioactively labeled probes specific to the gene of interest. Probe templates were obtained by PCR amplification of the cDNA insert from the respective I.M.A.G.E. clone that was used for microarray production, subsequently labeled with ${ }^{32} \mathrm{P}$ using the Prime-It RmT kit (Stratagene, Heidelberg, Germany). GAPD was used as calibrator. All Northern Blot analysis were performed at least three times.

\section{Western Blot Analysis}

For CCND1 and MYC detection, cells were rinsed twice in phosphate-buffered saline (PBS) and extracted in lysis buffer (140 mM NaCl, $4.7 \mathrm{mM} \mathrm{KCl,}$ $0.7 \mathrm{mM} \mathrm{MgSO}_{4}, 1.2 \mathrm{mM} \mathrm{CaCl}_{2}, 1 \mathrm{mM}$ HEPES $(\mathrm{pH}$
7.4), 1\% (v/v) Triton X-100, 2 mM PMSF, $20 \mu \mathrm{g} / \mathrm{ml}$ Leupeptin, $19 \mu \mathrm{g} / \mathrm{ml}$ Aprotinin, $100 \mathrm{mM}$ NaF, $2 \mathrm{mM}$ $\mathrm{Na}_{3} \mathrm{VO}_{4}, \quad 10 \mathrm{mM} \mathrm{Na}_{4} \mathrm{P}_{2} \mathrm{O}_{7} \times 10 \mathrm{H}_{2} \mathrm{O}$ ). The protein concentration was determined using the Biorad protein assay. An amount of $20 \mu \mathrm{g}$ of total protein was separated on 10\% SDS-PAGE gels. Separated proteins were transferred to a nitrocellulose membrane (Schleicher \& Schuell). The blots were then blocked with $5 \%(\mathrm{w} / \mathrm{v})$ nonfat dry milk in TBST before exposure to primary antibodies (anti-CCND1 (1/500; Becton, Dickinson and Company, Heidelberg, Germany), anti-MYC (1/500; Santa Cruz, CA, USA) and anti- $\alpha$-Tubulin (Sigma, Deisenhofer, Germany). The blots were then incubated with a horseradish peroxidase-conjugated goat anti-mouse secondary antibody (1/2000; Dako, Glostrup, Denmark). The signal was revealed with an ECL detection kit (Amersham Pharmacia Biotech, Freiburg, Germany).

\section{Results}

In order to shed light on E-cadherin-dependent gene expression, we have established a specialized cDNA microarray that we called 'Adhesion/Signaling Array'. Besides genes of signaling pathways (eg Wnt-, Notch-, Patched pathway) ( $n=306)$, the array contains genes related to growth and development $(n=115)$, adhesion $(n=101)$, repair and genomic instability $(n=71)$, cell cycle $(n=62)$ and a group of other interesting genes (eg transcription factors, apoptosis-related genes) $(n=244)$ (total of 899 unique sequences). We were mainly interested in cadherin-associated genes; therefore, we spotted genes relevant to cadherin function and signaling onto our in-house array and did not use a 'genomewide' array. In addition, data handling of a small array is much easier. We compared expression signatures of MDA-MB-435S cells expressing various E-cadherin mutants with the same cells expressing WT. The expression value for cells transfected with the wild-type molecule was set to 1 in each experiment. Therefore, there is no variation in gene expression for the wild-type expressing cells. For each of these experiments we performed four hybridizations. Each of the probes on the 'Adhesion/Signaling Array' was spotted twice or more. Thus, we obtained eight or more measurements for each probe. This allowed us to control array and hybridization quality through variance analysis. Additionally, common statistics could be applied to discover differentially expressed genes. Many of the differentially expressed genes were verified using Northern blot analysis and/or quantitative real time RT-PCR.

\section{Performance Comparison between Two Labeling Protocols}

We compared the performance of two different labeling techniques with our new 'Adhesion/Signaling 
Array', a direct and an indirect labeling method (see Materials and methods).

Scatterplots (Figure 1) indicate a more uniform variance for the directly labeled RNA and stronger nonlinearities in the smoother curve of the indirectly labeled RNA. Both effects are especially pronounced in the region of low expressed genes. In addition, the median ratio of variance between the two labeling techniques is 1.63 (indirect vs direct) indicating higher variance in the data from indirectly labeled RNA. This discrepancy in variance is also observed for the on-chip replicates (see Figure 2). Hence, in our experimental setup the direct labeling protocol outperforms the indirect labeling and is employed in all further studies.

\section{Quality Assessment}

In addition to the quality control intrinsic to our design of experiments (color swaps and replications), we performed control hybridizations of WT vs WT as well as MDA vs MDA ('same' vs 'same' hybridizations) to assess and prove the quality of our 'Adhesion/Signaling Array'. The mean genewise ratio variance among the four replicates is 0.46 .
Histograms of the genewise relative errors (Figure 3) show a high reproducibility among the on-chip replicates and a color-bias (due to fluorophore incorporation/labeling efficiency and scanner adjustment). The between-chip relative errors are comparable to the relative errors of the on-chip replicates.

\section{E-cadherin-Dependent Gene Expression Profiles}

We compared the expression profiles of five different MDA-MB-435S carcinoma cell clones. The original MDA-MB-435S cells lacking E-cadherin expression (MDA), cells expressing either E-cadherin with in-frame deletions of exon 8 (D8) or exon 9 (D9) or a point mutation in exon 8 (D370A) were all compared to wildtype (WT) E-cadherin-transfected cells. Stable expression of WT, D8, D9 or D370A E-cadherin proteins was confirmed by Western blot analysis and immunofluorescence staining (data not shown). All mutations affect the extracellular domains. The E-cadherin constructs were containing a $\beta$-actin promoter and not the original E-cadherin promoter. Since cells expressing D370A E-cadherin had the most scattered morphology and the highest
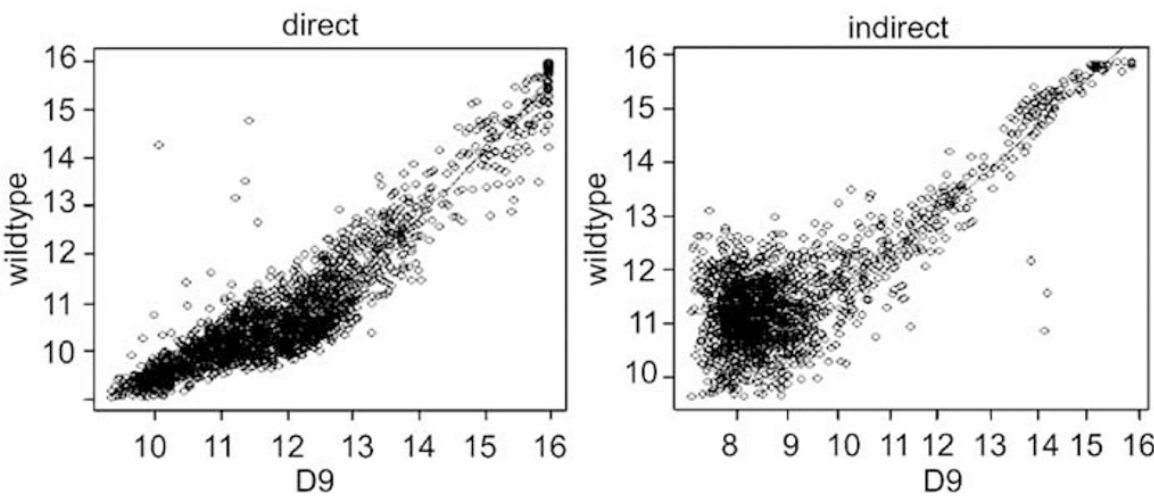

Figure 1 Scatterplots of expression values from two different labeling protocols. Scatterplots of expression values from two 'Adhesion/ Signaling Arrays' competitively hybridized with WT- and D9-RNA labeled according to two different labeling protocols ('direct' on the left, 'indirect' on the right). The line indicates the loess smoother curve.
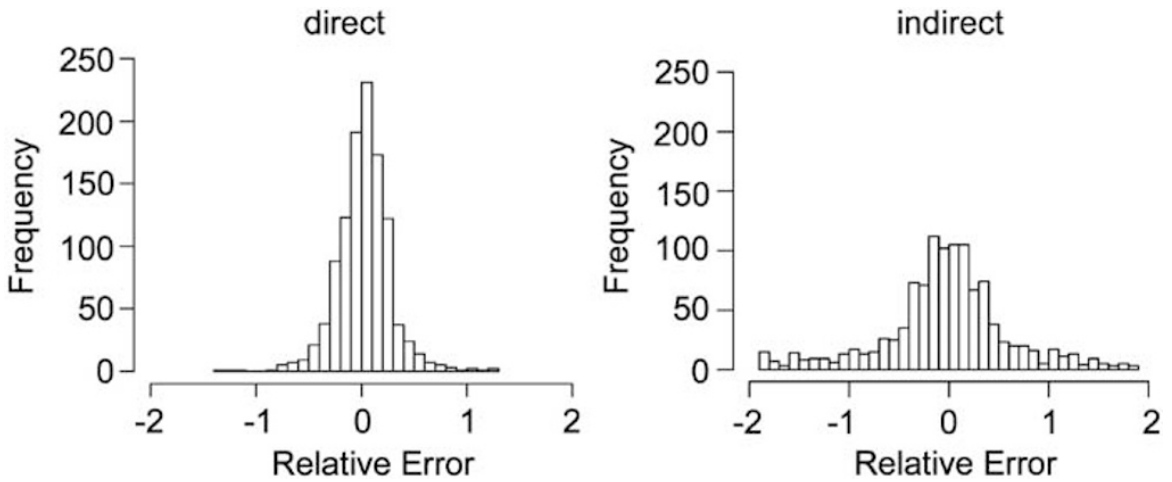

Figure 2 Histograms for the relative error from two different labeling protocols. Histograms for the relative error of expression values from two 'Adhesion/Signaling Arrays' competitively hybridized with WT- and D9-RNA labeled according to two different labeling protocols ('direct' on left, 'indirect' on right). For the definition of the relative error, see Materials and methods. 

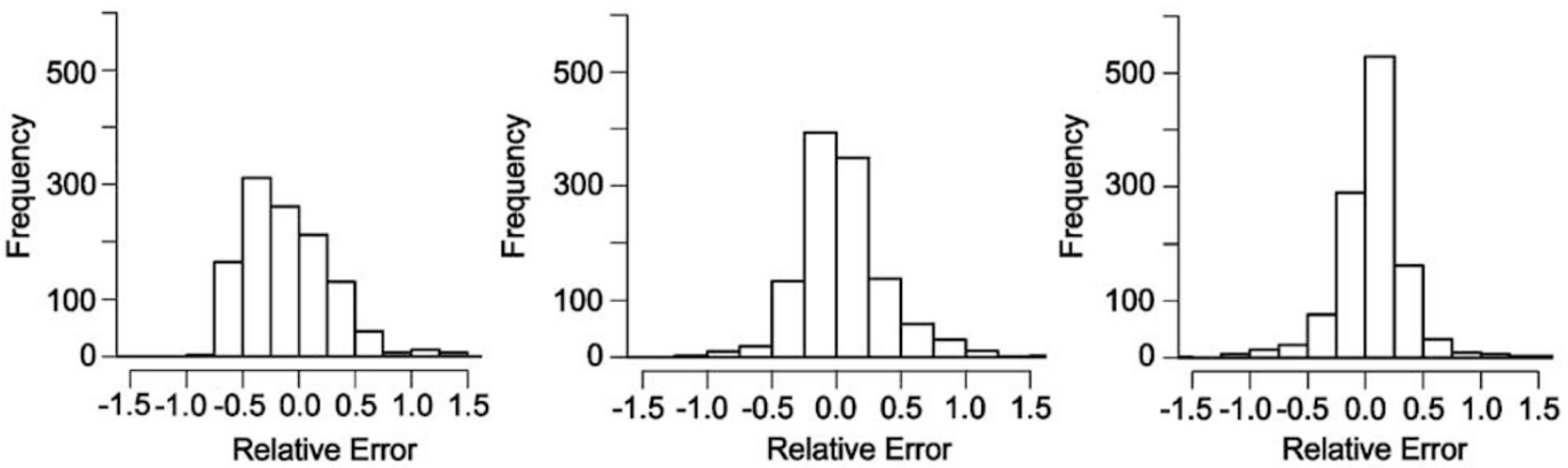

Figure 3 Histograms of the relative error. Histograms of the relative error of on-chip replicates (left), the two channels of a chip (middle panel), and two channels (same fluorophore) of separate chips (right panel). Raw data were used.

motility as demonstrated previously, ${ }^{57}$ we started analyzing expression profiles by comparing D370A cells with cells expressing WT. A subset of 38 genes was validated by Northern blot and/or quantitative real-time RT-PCR. Table 1 gives an overview of the results obtained by cDNA microarrays, Northern blot analysis and quantitative real-time RT-PCR for the hybridizations D370A vs WT. Of the 38 validated genes, we found 10 downregulated, 21 were upregulated and seven were not modulated. Additionally, we also examined expression of these 38 genes in D8, D9 and MDA cells. Over all investigated cell lines, our microarray results correspond to the Northern blot data in $92 \%$, that is, either up or downregulation. Thus we have demonstrated that our microarray results are well reproducible by quantitative real-time RT-PCR and Northern blot analysis. Based on these validations, we analyzed all cell lines for differentially expressed genes compared to WT cells focusing on Wnt signaling and E-cadherin repressors.

\section{Wnt Signaling Pathway Genes}

$\beta$-Catenin is bound at the cytoplasmatic tail of $\mathrm{E}$ cadherin; therefore the loss of E-cadherin could influence the quantity and location of cytoplasmatic $\beta$-catenin. First we proved that no endogenous but exogenous, transfected E-cadherin is expressed. Therefore, we have spotted E-cadherin probes onto our microarray, which are localized at the $3^{\prime}$ prime UTR sequence. That sequence is not included in the transfected E-cadherin construct and, consequently, could only detect endogenous E-cadherin. For these probes, we did not get any signal after microarray hybridization. The expression of the mutated Ecadherin was detected by mutation-specific antibodies ${ }^{64}$ and quantitative real-time RT PCR (data not shown).

In D8 and in D370A cells, $\beta$-catenin is located at punctuated cell contact areas and in the perinuclear Golgi region. ${ }^{65}$ Since $\beta$-catenin is also a key regulator of the Wnt-pathway, our special aim was now to elucidate the expression profiles of Tcf/Lef-regulated genes, the final targets of the Wnt signaling pathway. As MDA-MB-435S cells may be from melanoma origin and harbor $\beta$-catenin mutations, ${ }^{66-68}$ we sequenced the exon 3 of $\beta$-catenin in the MDA cells. Only the wild-type sequence was seen (data not shown). We focused our interest on 13 probes spotted onto our cDNA array known to be Tcf/Lef regulated. The corresponding fold changes are shown in Table 2. None of the target genes showed differential expression in the cell lines D370A, D9 and MDA. Only in D8 cells were the targets BMP4 (upregulated), CD44 (upregulated), FZD7 (downregulated) and MYC (upregulated) shown to be differential expressed (compared to WT cells). We validated three of these genes (AXIN2, CCND1 and MYC) by quantitative real-time RT-PCR and could not differential detect expression in any of our cell lines (ratio higher than 2 or less than 0.5) (Figure 4a). Also we determined the protein level of CCND1 and MYC by Western blot analysis. The protein expression of these genes was similar in all analyzed cell lines and no differentially expression could be found at all (Figure $4 \mathrm{~b}$ and c). Overall, these results indicate that E-cadherin mutations most likely have no influence on the Wnt-pathway.

Interestingly, our cDNA microarray results showed a significant upregulation of antagonists for the Wnt signaling pathway, the frizzled-related proteins SFRP1 and SFRP3. SFRPs, a family of secreted molecules, can interact with the Wnt proteins and block Wnt signaling and have negative effects on the intracellular $\beta$-catenin level. ${ }^{69-71}$ It has been postulated, that they act hereby as tumor suppressor genes. ${ }^{72,73}$ As validated by Northern blot, there is indeed an upregulation of SFRP1 and SFRP3. E-cadherin-negative MDA-MB-435S cells exhibited a 5.7-fold upregulation of SFRP1 and 5.1-fold upregulation of SFRP3 (Figure 5). Exon 8 mutated E-cadherin-transfected cells showed also an upregulation of the two genes compared to the wild-type transfected cells (D8: SFRP1 3.4-fold and SFRP3 2.4-fold; D370A: SFRP1 7.5- and SFRP3 7.2-fold). Additionally, a moderate upregulation (two-fold) of SFRP3 was found in exon 9 mutated E-cadherin transfected cells (Figure 5). 
Table 1 Validation of 38 selected genes by microarray, quantitative real-time RT-PCR and Northern blot

\begin{tabular}{|c|c|c|c|c|c|}
\hline Number & Gene name & $\begin{array}{l}\text { Accession } \\
\text { number }\end{array}$ & $\begin{array}{l}\text { cDNA array fold change } \\
\text { and standard deviation }\end{array}$ & $\begin{array}{l}\text { Northern blot fold change } \\
\text { and standard deviation }\end{array}$ & $\begin{array}{l}\text { TaqMan fold change and } \\
\text { standard deviation }\end{array}$ \\
\hline 1 & APOD & NM_001647 & $0.51 \pm 0.45$ & $0.68 \pm 0.13$ & ND \\
\hline 2 & p27kip1 & NM_004064 & $0.51 \pm 0.03$ & $0.40 \pm 0.05$ & ND \\
\hline 3 & PRKCD & NM_006254 & $0.52 \pm 0.33$ & $0.66 \pm 0.21$ & ND \\
\hline 4 & FGF13 & NM 004114 & $0.55 \pm 0.38$ & $0.04 \pm 0.03$ & ND \\
\hline 5 & PMX1 & NM_006902 & $0.56 \pm 0.43$ & $0.86 \pm 0.31$ & ND \\
\hline 6 & LAMA4 & NM_002290 & $0.61 \pm 0.23$ & ND & $0.70 \pm 0.17$ \\
\hline 7 & SLUG & NM_003068 & $0.62 \pm 0.30$ & ND & $0.43 \pm 0.05$ \\
\hline 8 & ARHGEF6 & NM_004840 & $0.65 \pm 0.36$ & ND & $0.39 \pm 0.00$ \\
\hline 9 & FUS & NM 004960 & $0.68 \pm 0.62$ & $0.61 \pm 0.26$ & ND \\
\hline 10 & PTN & NM_002825 & $0.75 \pm 0.18$ & $\overline{\mathrm{ND}}$ & $0.44 \pm 0.00$ \\
\hline 11 & FZD7 & NM 003507 & $0.86+0.37$ & ND & $0.78+0.21$ \\
\hline 12 & ZNF9 & NM_003418 & $0.87 \pm 0.22$ & $1.16 \pm 0.07$ & ND \\
\hline 13 & AXIN2 & NM_004655 & $0.97 \pm 0.79$ & ND & $1.53 \pm 0.01$ \\
\hline 14 & MYC & NM 002467 & $0.88 \pm 0.43$ & ND & $0.77 \pm 0.00$ \\
\hline 15 & TGFBR3 & XM_001924 & $0.98 \pm 0.57$ & ND & $0.86 \pm 0.00$ \\
\hline 16 & MXI1 & NM 005962 & $1.01+0.60$ & ND & $0.60+0.14$ \\
\hline 17 & CDKN2A & NM_000077 & $1.11 \pm 0.53$ & $1.42 \pm 0.58$ & ND \\
\hline 18 & CCND1 & NM_053056 & $1.23 \pm 0.75$ & $\overline{\mathrm{ND}}$ & $1.07 \pm 0.45$ \\
\hline 19 & TRA1 & NM_003299 & $1.30 \pm 0.49$ & $2.54 \pm 0.41$ & $\mathrm{ND}$ \\
\hline 20 & FGF1 & NM_000800 & $1.34 \pm 0.68$ & $1.21 \pm 0.17$ & ND \\
\hline 21 & TIMP1 & NM_003254 & $1.34 \pm 0.52$ & $3.43 \pm 1.24$ & ND \\
\hline 22 & CTSH & NM_004390 & $1.34 \pm 0.68$ & $2.45 \pm 0.62$ & ND \\
\hline 23 & RAD23B & NM_002874 & $1.36 \pm 0.14$ & $3.27 \pm 0.58$ & ND \\
\hline 24 & NME1 & NM_000269 & $1.43 \pm 0.34$ & $1.53 \pm 0.13$ & ND \\
\hline 25 & $\beta$-actin & NM_001101 & $1.46 \pm 0.39$ & $2.44 \pm 0.91$ & ND \\
\hline 26 & KPNA2 & NM 002266 & $1.46 \pm 0.40$ & $2.52 \pm 0.23$ & ND \\
\hline 27 & FAM3C & NM_014888 & $1.53 \pm 0.48$ & $1.40 \pm 1.21$ & ND \\
\hline 28 & ITGA3 & NM_005501 & $1.63 \pm 0.32$ & $2.78 \pm 0.42$ & $2.54 \pm 0.66$ \\
\hline 29 & CDH5 & NM_001795 & $1.88 \pm 0.20$ & $1.21 \pm 0.19$ & $\mathrm{ND}$ \\
\hline 30 & KRT18 & NM_000224 & $1.99 \pm 0.56$ & $4.86 \pm 3.25$ & ND \\
\hline 31 & MMP1 & NM 002421 & $2.08 \pm 0.95$ & $2.21 \pm 0.55$ & $5.75 \pm 0.61$ \\
\hline 32 & VEGFC & NM_005429 & $2.39 \pm 0.63$ & $2.77 \pm 1.00$ & $2.77 \pm 2.77$ \\
\hline 33 & CYR61 & NM_001554 & $2.41 \pm 0.94$ & $1.42 \pm 0.62$ & $2.97 \pm 0.17$ \\
\hline 34 & FRZB (SFRP3) & NM_001463 & $2.73 \pm 0.68$ & $7.23 \pm 2.47$ & $\mathrm{ND}$ \\
\hline 35 & SPARC & NM_003118 & $2.81 \pm 0.26$ & $2.60 \pm 0.27$ & ND \\
\hline 36 & MMP3 & NM_002422 & $3.20 \pm 0.73$ & $\infty \pm-$ & $56.28 \pm 1.63$ \\
\hline 37 & CTNNAL1 & NM_003798 & $3.60 \pm 0.49$ & $6.69 \pm 1.40$ & $\mathrm{ND}$ \\
\hline 38 & SFRP1 & NM_003012 & $4.26 \pm 0.43$ & $7.50 \pm 3.05$ & ND \\
\hline
\end{tabular}

Analysis of 36 selected genes that were found to be differentially expressed by microarray analysis (D370A compared to WT cells). Almost all of the genes could be verified using Northern blot and/or quantitative real-time RT-PCR. Gene numbers 12 (ZNF9) and 14 (MXI1) showed conflicting results, but was not considered to be differentially expressed, giving a verification rate of $94 \%(34 / 36)$. These validations were also performed over all cell lines (D8, D9 and MDA compared to WT), giving an overall verification rate of $92 \%$. The low variance (measured as SD) in the quantitative real-time RT-PCR analysis is completely due to the RT-PCR intrinsic measurement error, while the high variance of the microarray data is a summary of various error components such as labeling and extraction protocol, microarray slide and spot position.

In addition, we found a relation between reported E-cadherin-dependent adhesion of the cell lines and P27KIP1. The highest motility and lowest adhesion exhibited by D8 and D370A cell lines ${ }^{57}$ correlate with the lowest expression of P27KIP1 (4.4-fold downregulated in D8 and 2.5-fold downregulated in D370A verified by Northern blot). Increasing P27KIP1 expression reflects increasing cell adhesion, which is almost completely mirrored in Figure 6 (in order: D8, D370A, D9, MDA and WT).

\section{E-cadherin Repressors SNAIL, SLUG, TWIST, SIP1, ZEB1 and E12/E47}

Since the expression of Wnt signaling pathway genes was not markedly affected by the different E-cadherin variants, we also analyzed regulators of
E-cadherin gene expression. SLUG, SNAIL, E12/ E47, ZEB1 and SIP1 are involved in EMT by repressing E-cadherin via an E-box element in the proximal E-cadherin promoter. TWIST is a transcription factor, containing a helix-loop-helix DNAbinding domain, described as an activator of N-cadherin during Drosophila embryogenesis. A strong inverse correlation between SLUG, SNAIL and SIP1 expression and loss of E-cadherin were shown in breast cancer cell lines. ${ }^{48,53}$ Interestingly, we found a downregulation of most E-cadherin repressors as analyzed by quantitative real-time RT-PCR in cells expressing abnormal E-cadherin compared to cells expressing WT (Figure 7a,b). The expression levels of the E-cadherin repressors were too low to be detected by microarray analysis or no probes were represented on our 'Adhesion/Signaling Array'. Additionally, we found expression 
Table 2 Ratios of Tcf/Lef-transcribed genes

\begin{tabular}{|c|c|c|c|c|c|c|c|c|c|c|}
\hline \multirow[t]{2}{*}{ Number } & \multirow{2}{*}{$\begin{array}{l}\text { Gene } \\
\text { symbol }\end{array}$} & \multirow[t]{2}{*}{ RefSeq } & \multicolumn{2}{|c|}{$D 8$} & \multicolumn{2}{|c|}{$D 370 A$} & \multicolumn{2}{|c|}{ D9 } & \multicolumn{2}{|c|}{$M D A$} \\
\hline & & & $\begin{array}{c}\text { Fold } \\
\text { change }\end{array}$ & $\begin{array}{l}\text { Standard } \\
\text { deviation }\end{array}$ & $\begin{array}{c}\text { Fold } \\
\text { change }\end{array}$ & $\begin{array}{l}\text { Standard } \\
\text { deviation }\end{array}$ & $\begin{array}{c}\text { Fold } \\
\text { change }\end{array}$ & $\begin{array}{l}\text { Standard } \\
\text { deviation }\end{array}$ & $\begin{array}{c}\text { Fold } \\
\text { change }\end{array}$ & $\begin{array}{l}\text { Standard } \\
\text { deviation }\end{array}$ \\
\hline 1 & AXIN2 & NM_004655 & 0.99 & 0.08 & 0.97 & 0.79 & 0.98 & 0.34 & 1.04 & 0.11 \\
\hline 2 & BMP4 & NM_001202 & 1.42 & 0.46 & 1.15 & 0.47 & 1.16 & 0.71 & 1.07 & 0.19 \\
\hline 3 & CCND1 & NM_053056 & 1.08 & 0.15 & 1.13 & 0.54 & 1.14 & 0.34 & 1.01 & 0.10 \\
\hline 4 & CD44 & NM_000610 & 1.53 & 0.66 & 1.02 & 0.30 & 0.91 & 0.19 & 1.32 & 0.69 \\
\hline 5 & FZD7 & NM 003507 & 0.66 & 0.39 & 0.90 & 0.30 & 0.86 & 0.34 & 0.79 & 0.28 \\
\hline 6 & JUN & NM_002228 & 0.97 & 0.13 & 1.07 & 0.37 & 1.09 & 0.23 & 0.99 & 0.08 \\
\hline 7 & LEF1 & NM_016269 & 1.06 & 0.22 & 1.00 & 0.18 & 1.04 & 0.83 & 1.05 & 0.16 \\
\hline 8 & MMP7 & NM_002423 & 1.01 & 0.17 & 0.95 & 0.70 & 0.91 & 0.33 & 1.06 & 0.26 \\
\hline 9 & MYC & NM_002467 & 1.40 & 0.26 & 0.88 & 0.43 & 1.21 & 0.48 & 0.95 & 0.13 \\
\hline 10 & PLAUR & NM 002659 & 0.93 & 0.34 & 1.06 & 0.84 & 1.07 & 0.43 & 1.01 & 0.08 \\
\hline 11 & PPARD & NM_006238 & 1.03 & 0.11 & 0.89 & 0.25 & 1.06 & 0.42 & 0.96 & 0.15 \\
\hline 12 & TCF1 & NM_000545 & 1.02 & 0.12 & 1.00 & 0.28 & 0.96 & 0.37 & 0.98 & 0.29 \\
\hline 13 & VEGF & NM_003376 & 1.09 & 0.39 & 0.91 & 0.59 & 0.83 & 0.49 & 1.07 & 0.27 \\
\hline
\end{tabular}

cDNA microarray data (ratios) of Tcf/Lef-transcribed genes for D8, D370A, D9 and MDA. Except of BMP4, MYC, CD44 and FZD7 by D8 cells none of the 13 Tcf/Lef-transcribed genes showed an up- or downregulation compared to WT-transfected MDAs. Amount of $50 \mu \mathrm{g}$ total RNA were used for cDNA microarray analysis.

differences between the cell lines (Figure 7a,b). Not all repressors were found to be downregulated in all cell lines equally. In D8 cells, the expression of all repressors except E12/E47 was downregulated. In contrast, in D370A cells SNAIL, TWIST, ZEB1 and E12//E47 did not show expression changes. In D9 cells, expression of SIP1 did not change, whereas SNAIL was found to be even upregulated. Compared to WT cells, in MDA cells all six repressors were found to be downregulated. Note that the E-cadherin expression in our transfectants is mediated by the expression vector pBATEM. ${ }^{36,74}$ A $\beta$-actin promoter and not the original E-cadherin promoter is located $5^{\prime}$ of the E-cadherin constructs, therefore SLUG, SNAIL, SIP1, TWIST and ZEB1 repression could not influence E-cadherin expression in our transfected cells.

\section{Discussion}

In this study we have established a specialized custom microarray ('Adhesion/Signaling Array') to examine the influence of E-cadherin on gene expression. We found many differentially expressed genes between mutated and WT transfectants. In total, $92 \%$ of the genes that we examined with quantitative analysis (real time RT-PCR and Northern blots) showed a correlation to our microarray data regarding to up- or downregulation. Although E-cadherin may modulate Wnt, almost no Wnt target genes were differentially expressed. On the other hand, the expression of E-cadherin repressors was significantly reduced in the E-cadherin variants. Our 'Adhesion/Signaling Array' is suitable for further E-cadherin-dependent analysis, such as germline mutations, EMT, hypoxia and many more applications.

\section{Role of E-cadherin for Wnt Signaling}

$\beta$-Catenin has been shown to exert two signaling functions. On the one hand, it has a crucial role in cell-cell adhesion and on the other hand it is a component of the Wnt signaling pathway. As $\beta$ catenin interacts with E-cadherin at the cell membrane, a participation of E-cadherin in the Wnt signaling was suggested. $\beta$-Catenin activates Wnttarget genes in the nucleus through formation of a transcriptionally active complex with members of the Tcf/Lef family of transcription factors. Target genes of this complex are CCND1, TCF1, MYC and others (see Table 2). Rubinfeld ${ }^{68}$ found that six of 27 melanoma cell lines have $\beta$-catenin mutations in exon 3 affecting the $\mathrm{N}$-terminal phosphorylation sites. In contrast the studies of Demunter ${ }^{66}$ and Pollock ${ }^{67}$ describe that $\beta$-catenin mutations are more rarely seen in melanoma cells. To exclude that our results are based on $\beta$-catenin mutations we sequenced exon 3 , but no mutation could be found. Therefore, $\beta$-catenin mutations affecting exon 3 could not have influenced our results. Orsulic et $a l^{55}$ described a competition for $\beta$-catenin between E-cadherin and LEF-1. In E-cadherin-negative embryonic stem cells and in SW480 colon carcinoma cells accumulation of free $\beta$-catenin and its association with LEF-1 takes place. $\beta$-Catenin/LEF-1mediated trans-activation in these cells was antagonized by transient expression of WT, but not of E-cadherin lacking the $\beta$-catenin-binding site. Therefore, E-cadherin has the ability to recruit free $\beta$-catenin to the cell membrane and prevent its nuclear localization and trans-activation. The idea that Wnt signaling and E-cadherins compete for the same pool of $\beta$-catenin is primarily based on work with Xenopus and Drosophila. In Xenopus expression of various Wnt genes in ventral blastomeres 


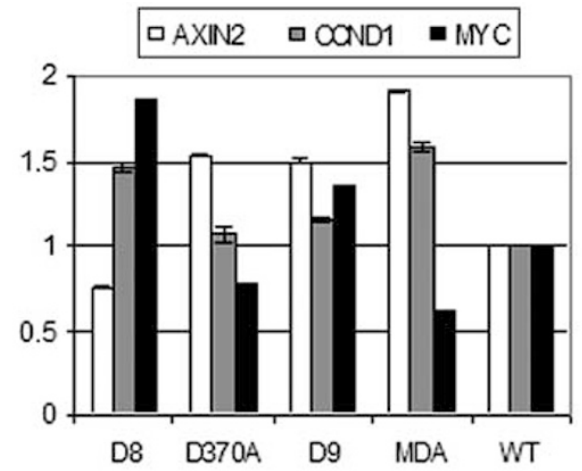

b

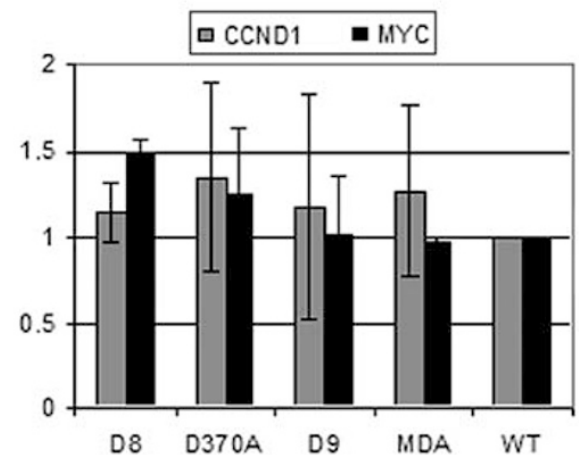

C

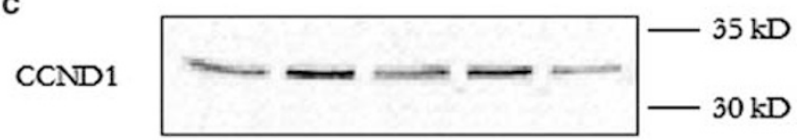

MYC
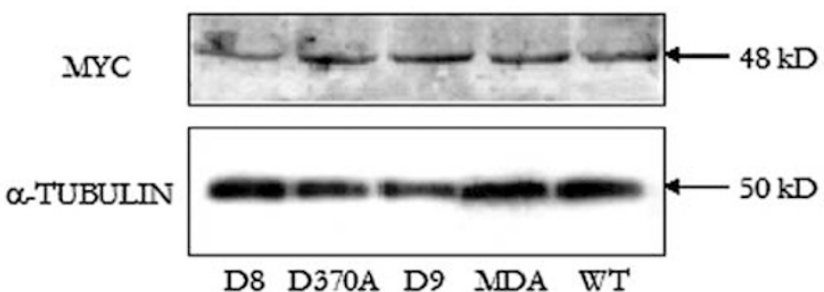

Figure 4 RNA and protein expression of TCF/LEF-regulated genes. (a) Quantitative real-time RT-PCR data for AXIN2, CCND1 and MYC expression (GAPDH was used as calibrator). No differentially expression (over 2.0 or less than 0.5 ) could be detected. (b) Western blot analysis of CCND1 and MYC. No differential protein expression could be detected in any of these cell lines. (c) Equal amounts $(20 \mu \mathrm{g})$ of protein lysate from D8, D370A, D9, MDA and WT were analyzed for CCND1 and MYC expression by Western blotting (three Western blots for each gene). $\alpha$-TUBULIN was used as calibrator.

results in dorsalization and axis duplication. ${ }^{75}$ The same effect is obtained by ectopic $\beta$-catenin. ${ }^{76}$ Injection of high levels of ectopic E-cadherins inhibits dorsal axis formation, suggesting that Ecadherins compete with Wnts and deplete the signaling-competent pool of $\beta$-catenin. ${ }^{77-79}$ Gottardi et $a l^{56}$ also described that E-cadherin affects Wnt signaling. In their study, SW480 colorectal tumor cells were transfected with different E-cadherin constructs. E-cadherin constructs with a $\beta$-cateninbinding region had effects on LEF/TCF reporter gene activity, but E-cadherin constructs lacking the $\beta$ catenin-binding region had no effect. a

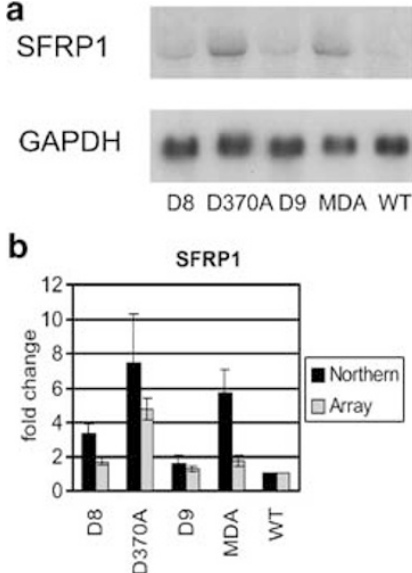

SFRP3

GAPDH

8370A D9 MDA WT

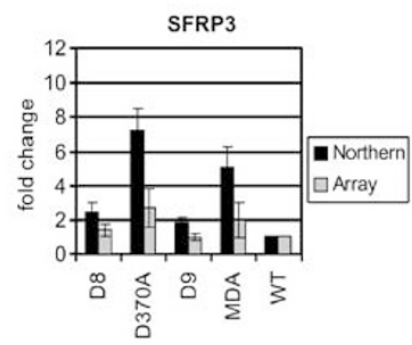

Figure 5 Microarray and Northern blot data for SFRP1 and SFRP3 expression. (a) Equal amounts $(10 \mu \mathrm{g})$ of total RNA from D8, D370A, D9, MDA and WT were size-separated by agarose gel electrophoresis, transferred to a Nylon membrane and hybridized with radiolabeled probes specific to the genes indicated. GAPDH was used as calibrator. (b) Comparison between Northern blot and array data of SFRP1 and SFRP3, showing similarities with regard to the direction of differential expression.

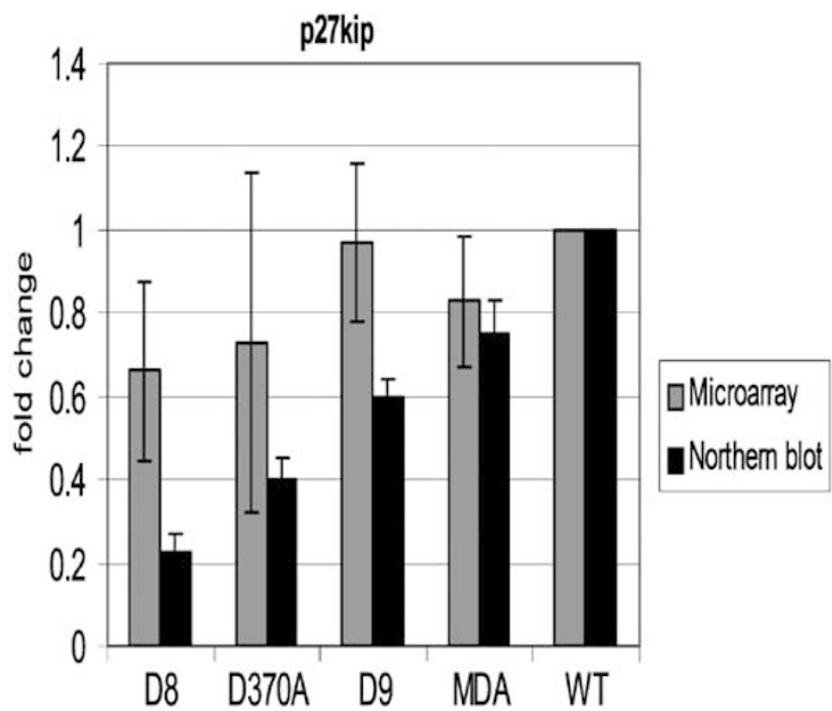

Figure 6 Microarray and Northern Blot data for P27KIP1 expression. P27KIP1 expression is decreased in cells expressing mutated E-cadherin in exon 8 (D8, D370A). Thus, defective cell-to-cell contact as seen in D8 and D370A cells may result in downregulation of P27KIP1. Amount of $50 \mu \mathrm{g}$ total RNA were used for cDNA microarray analysis.

First, we also expected like Orsulic ${ }^{55}$ or Gottardi ${ }^{56}$ an upregulation of Tcf/Lef-regulated genes in Ecadherin-negative MDA cells, since no $\beta$-catenin can be bound at the cytoplasmatic membrane to this adhesion molecule. We suspected a similar effect in cells transfected with mutated E-cadherin. However, we found almost no expression differences of Tcf/ Lef-regulated genes in the transfectants D8 (except for five genes), D370A, D9 and untransfected MDA cells compared to WT transfectants by microarrays. Additionally, the validation of AXIN2, CCND1 and MYC by quantitative real-time RT-PCR as well as the 


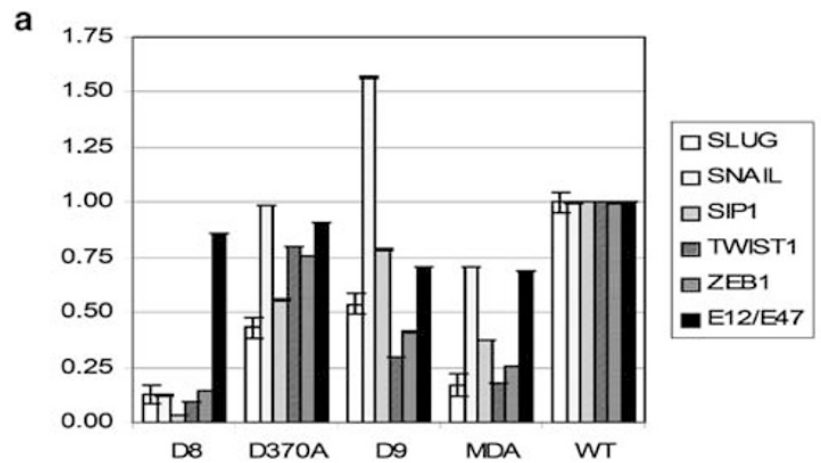

b
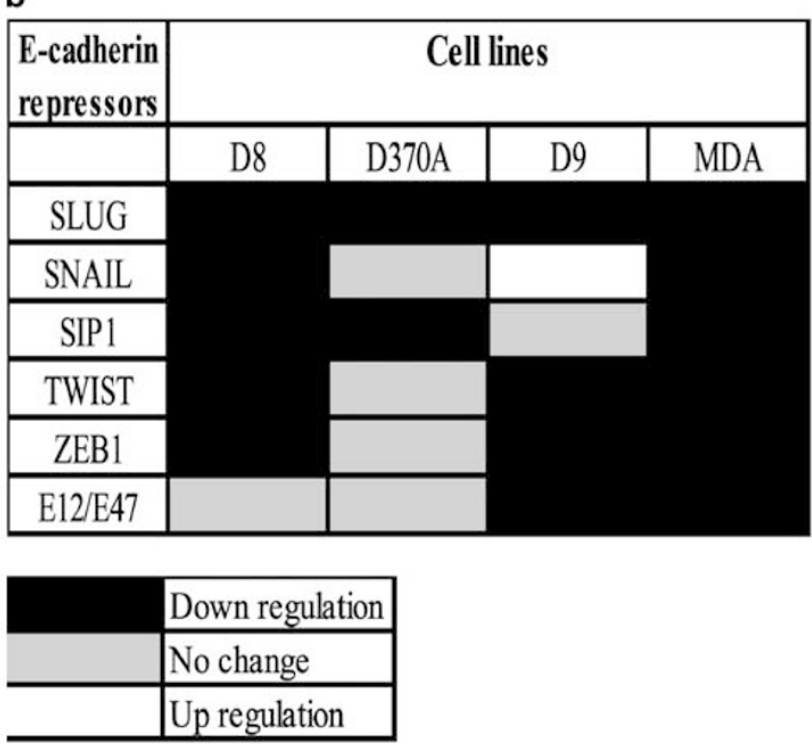

Figure 7 Expression profiles of E-cadherin repressors. (a) Expression profiles of SLUG, SNAIL SIP1, TWIST, ZEB1 and E12/E47 determined by quantitative real-time RT-PCR. Lack of upregulation of E-cadherin repressors were mainly found in transfectants without functional or lacking E-cadherin. GAPDH was used as calibrator. (b) Expression matrix for the E-cadherin repressors. Black, downregulation; gray, no change; white, upregulation.

determination of protein expression of CCND1 and MYC by Western blot analysis indicate no differentially expression and confirmed our microarray data. Accordingly, Luber et $a l^{65}$ analyzed the distribution of $\beta$-catenin. $\beta$-Catenin was, independently of the $\mathrm{E}$ cadherin functional status, stabilized at lateral cellto-cell contact sides compared to the parental cells and, in addition, also found abnormally located in the perinuclear region. But it was not found within the nucleus. These findings support our data very well, but they are contradictory to the results of Orsulic $^{55}$ or Gottardi ${ }^{56}$ described before. One explanation for these findings may be the expression of $\mathrm{N}$-cadherin, which prevents $\beta$-catenin from translocation to the cell nucleus. Another explanation is based on the upregulation of SFRP1 and SFRP3 in D8, D370A and MDA cells (Figure 5). SFRPs are soluble molecules capable of binding Wnts and preventing the activation of their signaling cascade. Thereby, SFRPs antagonize the Wnt-in- duced increase of uncomplexed $\beta$-catenin and TCF transcription. ${ }^{80}$ According to our results, defective or missing E-cadherin leads to an upregulation of SFRP1 and SFRP3 compensating the missing or decreased ability of E-cadherin recruiting $\beta$-catenin to the cell membrane and preventing its nuclear localization (Figure 8). Also in line with these findings is the downregulation of FZD7, the receptor of Wnt-proteins, in D8 (data not shown), D370A (Table 1 Nr.: 11), and MDA (data not shown).

Lack of E-cadherin involvement in the Wnt pathway was also described before by Marc van de Wetering et $a l^{81}$ where a TCF reporter gene was transiently transfected into 15 breast cancer cell lines. Neither cells with mutated E-cadherin nor cells with transcriptional downregulation of the E-cadherin gene showed TCF-mediated transcriptional activation, confirming our results that E-cadherin variants or absence of E-cadherin had almost no effect on 13 Tcf/Lef-transcribed genes represented on our 'Adhesion/Signaling Array'. Similar results were found by Caca, ${ }^{82}$ who analyzed TCF transcription by gastric, breast and pancreatic cancer cell lines with reduced or lack of E-cadherin expression. Loss of endogenous E-cadherin expression was not associated with significant increases in $\beta$-catenin levels, and no evidence for constitutive TCF transcriptional activity was found in any of the cell lines lacking endogenous E-cadherin expression. This is in line with our findings. Upregulation of some Tcf/Lef-regulated genes found in D8 cells, such as BMP4, CD44 and MYC, could be caused by a 1.7-fold higher expression of MADH3 seen in these cells (data not shown). MADH3 acts as transcriptional comodulator regulating target gene expression by interacting with LEF1/TCF and $\beta$-catenin at Xtwn promoter. A synergistical transcription activity occurs. Weaker transcription of the same target genes arises with $\beta$-catenin or MADH3/4 alone. ${ }^{83}$ It has been shown that Smad-regulation is mediated by an 8-bp sequence element (SBE, Smad-binding element) that is specifically bound by MADH3/4. ${ }^{84}$ In a preliminary study we looked for SBEs in the upstream regulatory sequences of the Tcf/Lef-regulated genes (unpublished observations). Two or more of the $8 \mathrm{bp}$ motifs are correlating to a high binding efficiency to MADH3. We found two or more SBEs in the $5000 \mathrm{bp}$ upstream sequences of BMP4, CD44, MYC and VEGF, but not in any of the other Tcf/Lef-transcribed genes. Thus, the controversial upregulation of BMP4, CD44 and MYC in D8 cells may have resulted from upregulation of MADH3 rather than from expression of the truncated E-cadherin in D8 cells.

\section{E-cadherin Influences Expression of E-cadherin Repressors}

E-cadherin expression is often downregulated during tumor progression, which is associated with 


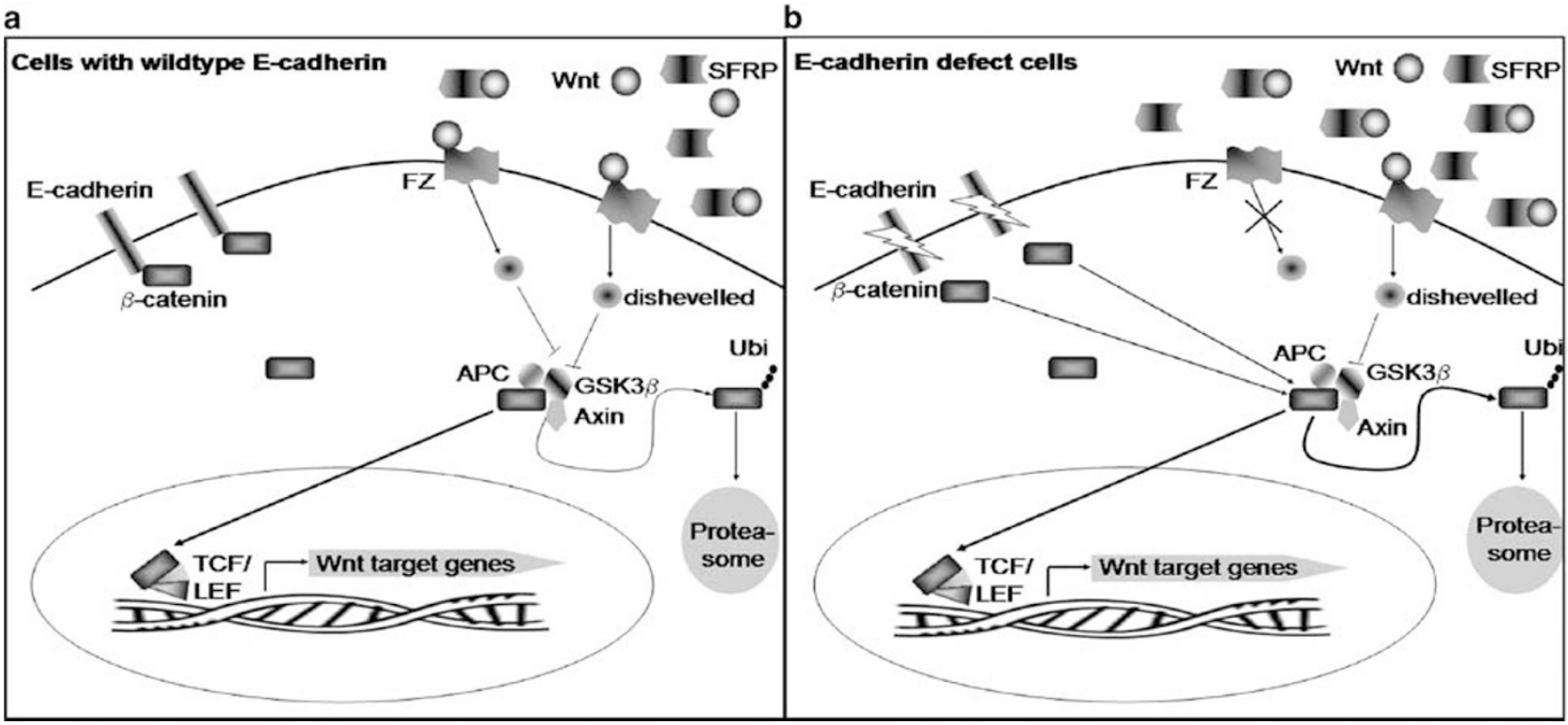

Figure 8 Molecular comparison between cells expressing normal or defective E-cadherin. (a) Cancer cells with wildtype E-cadherin and (b) cancer cells with mutated E-cadherin. In cells expressing normal E-cadherin the pool of free cytoplasmic $\beta$-catenin is minimal, but less $\beta$-catenin is degraded because of minor secretion of SFRPs. Expression of defective E-cadherin may result in a higher secretion of SFRPs which causes capping of Wnts; less Wnts can bind to FZ. Activation of DVL is reduced followed by a higher activity of GSK3 $\beta$ and increased degradation of free cytoplasmic $\beta$-catenin (bold arrow) compared to WT. Thus, E-cadherin mutations may have no major influence on Tcf/Lef-regulated genes.

dedifferentiation and invasiveness of carcinoma cells. $^{85-88}$ Constitutive expression of E-cadherin decreases cell invasiveness, ${ }^{86,88-90}$ although the exact mechanism for this suppressive role of Ecadherin in tumor development still is not known. A great insight into the molecular mechanism underlying E-cadherin downregulation has been provided in recent years by the findings of genetic and epigenetic mechanisms acting in tumors and cancer cell lines. ${ }^{40,91}$ Analysis of the gene regulatory elements in the human and mouse E-cadherin genes has greatly supported the notion that repressors bound to proximal E-boxes of the E-cadherin promoter are major players in transcriptional repression in a variety of cell-lines origin. ${ }^{92-96}$ Indeed, several E-cadherin transcriptional repressors have been characterized in the past 4 years that interact with the proximal E-boxes of the promoter. ${ }^{38,39,53,97}$

We found a downregulation of all six E-cadherin repressors SLUG, SNAIL, SIP1, TWIST, E12/E47 and ZEB1 in the untransfected MDA cells, a high downregulation between 7.8 and 26.6-fold in D8 cells (except E12/E47) and a downregulation of SLUG and SIP1 in D370A cells compared to wildtype MDAs (Figure 7a, b). Previously, it was reported that D8 and D370A cells possess, besides their E-cadherin localization at the lateral regions of cellto-cell contact sites, an apical and perinuclear localization of E-cadherin. ${ }^{57}$ Cells expressing E-cadherin mutated in exon 8 showed the most scattered appearance, whereas cells with deletion in exon 9 had an intermediate state. MDA cells transfected with WT have a higher expression of E-cadherin repressors as shown in this study probably due to counter-regulatory mechanisms (see below). These cannot, however, be effective as in our cell system E-cadherin is under control of a $\beta$-actin promoter and we have proven that the expression level of E-cadherin are not affected (data not shown). The data of our study for the first time suggest that mutated E-cadherin causes a lack of upregulation of SLUG, SIP1, TWIST, SNAIL and ZEB1 and fail to induce the counter regulatory mechanisms proposed below. As shown in Figure 9 normal epithelial cells show a low expression pattern of E-cadherin repressors, they have a strong cell-to-cell contact mediated by E-cadherin, inhibiting invasiveness. In contrast, tumor cells exhibiting a higher level of E-cadherin repressors, express less E-cadherin followed by higher invasiveness of the cells. $^{35,36}$ This increased invasion potential could also be based on E-cadherin mutations.

Many tumor cells maintain strong intercellular adhesion and are growth inhibited by cell-to-cell contact, but not in the same range as normal cells. Growth arrest in response to cell-cell contact is coregulated by P27KIP1, a cyclin-dependent kinase inhibitor and member of the KIP family. ${ }^{98}$ It was shown, that E-cadherin besides its function as an invasion suppressor also acts as a major growth suppressor. ${ }^{54}$ Its ability to inhibit proliferation involves upregulation of the cyclin-dependent kinase inhibitor P27KIP1. Findings in our study confirm these results. MDAs transfected with WT or 


\section{Tumor Cells}
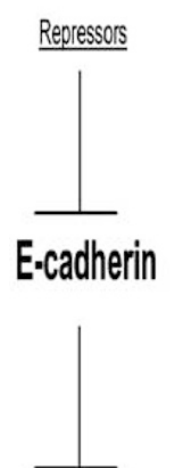

Invasion

Metastasis
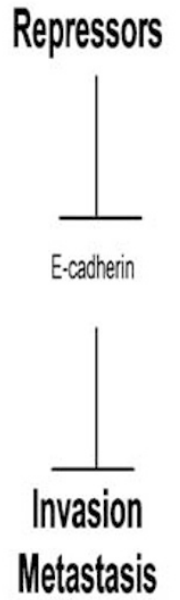
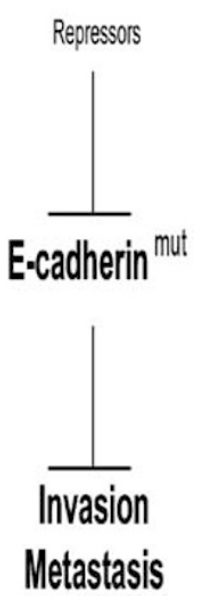

Figure 9 E-cadherin repressors, E-cadherin mutations and the invasion/metastasis potential in context. Diagram integrating E-cadherin repressors, E-cadherin mutations and the invasion/ metastasis potential in normal epithelial cells and tumor cells. In nontumorous cells, strong E-cadherin expression due to absence of repressors prevents invasion and metastasis because of stable cell-to-cell contacts. In tumor cells, however, either E-cadherin repressors are upregulated resulting in downregulation of Ecadherin and increased invasion potential or E-cadherin mutations actively contribute to invasion and metastasis, without changes in expression of E-cadherin repressors.

D9 E-cadherin exhibit tighter cell adhesion in comparison to D370A, D8 E-cadherin-transfected cells and untransfected E-cadherin-negative MDAs. ${ }^{57}$ Our microarray findings for P27KIP1 are in line with these results. We found a lower expression of P27KIP1 in D370A and D8 cells (more than two-fold) compared to WT cells. According to these findings, E-cadherin-dependent cell-to-cell contacts may upregulate P27KIP1 expression and thereby influence proliferation.

Cell-to-cell contact may also play a role in regulation of the E-cadherin repressors. E-cadherinmediated cell adhesion plays a critical role in early embryonic development, where numerous phenotypic changes occur through EMT. The acquisition of a fibroblastic phenotype is accompanied by the loss of E-cadherin and allows cells to dissociate from epithelial tissue and to migrate freely. The maintenance of stable cell-to-cell contacts and cell polarity is an essential requirement for the functionality and homeostasis of epithelial tissues in the adult organism. This strict tissue organization is lost during the progression of epithelial tumors (carcinomas) and is particularly evident at the invasion stage when tumor cells dissociate from the primary tumor and require the ability to traverse the basement membrane that separates the epithelial tissue from the adjacent connective tissue. ${ }^{99,100}$ During EMT a stable expression of SLUG leads to the full repression of E-cadherin at transcriptional level and the loss of cell-to-cell contact. ${ }^{101}$ In our cellular system D8 cells have already lost their cell-to-cell contact (due to the nonfunctional E-cadherin molecule) without repression of E-cadherin. In contrast, WT-transfected cells have a tight cell-to-cell contact $^{57}$ and in order to become invasive, downregulation of E-cadherin expression is required.

Our findings correspond to the results of Rosivatz, ${ }^{44}$ who investigated 20 intestinal type gastric cancers and found in cases with reduced E-cadherin expression an upregulation of SIP1. However, in the same study, 28 primary diffuse type gastric carcinomas were investigated but the role of SNAIL, SIP1 or TWIST was unclear. In total, 11 cases showed reduced E-cadherin expression; upregulation of E-cadherin repressors was seen in all of these cases except of one tumor. In six other cases, upregulation of the repressors was seen but downregulation of E-cadherin could not be found. From 17 cases showing E-cadherin mutations, eight cases were found to have unchanged expression pattern of the repressors, indicating that expression of a nonfunctional E-cadherin but not reduction of E-cadherin expression levels contributes to the scattered phenotype that is typically seen in diffuse-type gastric cancer. In contrast, our cell system is artificial with regard to the heterologous E-cadherin promoter, which does not allow the normal cellular regulation of Ecadherin. All our cell lines were compared to the WT-transfected MDA cells. These cells showed an interesting unexpected behavior. They have a tight cell-to-cell contact indicating functional WT E-cadherin levels, ${ }^{57}$ and simultaneously (Figure 8) significant higher levels of E-cadherin repressors as compared to MDA cells. These seemingly contradicting results have their basis in the $\beta$-actin promoter, which does not allow downregulation of E-cadherin, which obviously seems to trigger enhanced expression of the E-cadherin repressor in WT-transfected cells. This working hypothesis is well supported by the results in cells without cell-to-cell contact as D8 or D370A. These cell lines have no functional E-cadherin simulating an 'Ecadherin low' status. Consequently, the expression levels of E-cadherin repressors are the same as or even lower than in MDA cells. This is a strong argument that invasive cells 'sense' cell-to-cell contact and in line with our increased expression of E-cadherin repressors. Transfectants with mutated E-cadherin have low repressor levels since they possess per se inactive E-cadherin and have lost their cell-to-cell contact. They show the same or lower expression level of E-cadherin repressors as MDAs. However, because of the 'wrong' E-cadherin promoter ( $\beta$-actin promoter) E-cadherin repressors have no effect in our system on E-cadherin itself. In conclusion, our results show that mutated Ecadherin does not stimulate the upregulation of E-cadherin repressors, whereas functional WT E-cadherin causes their upregulation. The exact 
mechanisms how defective E-cadherin influences gene expression, however, has to be determined.

\section{Acknowledgements}

We thank Erika Rosivatz and Catarina Alves for some primer and probes and Drs Xenia Mazur and Mike Atkinson for critically reading the manuscript. The study was supported in part by a grant from the Deutsche Krebshilfe Grant No. 102012-Be3 to KFB and HH and FKZ 01650105 to HH from the German Ministry for Education and Research (BMBF). We thank J Adamski (GAC-GSF) for instrumental supply.

\section{References}

1 Takeichi M. Cadherin cell adhesion receptors as a morphogenetic regulator. Science 1991;251:14511455.

2 Nagafuchi A, Takeichiv M. Cell binding function of E-cadherin is regulated by the cytoplasmic domain. EMBO J 1988;7:3679-3684.

3 Ozawa M, Kemler R. Correct proteolytic cleavage is required for the cell adhesive function of uvomorulin. J Cell Biol 1990;111:1645-1650.

4 Behrens J, von Kries JP, Kuhl M, et al. Functional interaction of beta-catenin with the transcription factor LEF-1. Nature 1996;382:638-642.

5 Huber O, Korn R, McLaughlin J, et al. Nuclear localization of beta-catenin by interaction with transcription factor LEF-1. Mech Dev 1996;59:3-10.

6 Huelsken J, Behrens J. The Wnt signalling pathway. J Cell Sci 2002;115(Part 21):3977-3978.

7 Cadigan KM, Nusse R. Wnt signaling: a common theme in animal development. Genes Dev 1997;11: 3286-3305.

8 Dale TC. Signal transduction by the Wnt family of ligands. Biochem J 1998;329(Part 2):209-223.

9 Miller JR, Hocking AM, Brown JD, et al. Mechanism and function of signal transduction by the Wnt/betacatenin and $\mathrm{Wnt} / \mathrm{Ca}^{2+}$ pathways. Oncogene 1999;18: 7860-7872.

10 Jones SE, Jomary C. Secreted Frizzled-related proteins: searching for relationships and patterns. Bioessays $2002 ; 24: 811-820$.

11 Julius MA, Schelbert B, Hsu W, et al. Domains of axin and disheveled required for interaction and function in wnt signaling. Biochem Biophys Res Commun 2000;276:1162-1169.

12 Rubinfeld B, Albert I, Porfiri E, et al. Binding of GSK3beta to the APC-beta-catenin complex and regulation of complex assembly. Science 1996;272: 1023-1026.

13 Gumbiner BM. Signal transduction of beta-catenin. Curr Opin Cell Biol 1995;7:634-640.

14 Rubinfeld B, Souza B, Albert I, et al. Association of the APC gene product with beta-catenin. Science 1993;262:1731-1734.

$15 \mathrm{Su}$ LK, Vogelstein B, Kinzler KW. Association of the APC tumor suppressor protein with atenins. Science 1993;262:1734-1737.
16 Behrens J, Jerchow BA, Wurtele M, et al. Functional interaction of an axin homolog, conductin, with betacatenin, APC, and GSK3beta. Science 1998;280: 596-599.

17 Hart MJ, de los Santos R, Albert IN, et al. Downregulation of beta-catenin by human Axin and its association with the APC tumor suppressor, betacatenin and GSK3 beta. Curr Biol 1998;8:573-581.

18 Ikeda S, Kishida S, Yamamoto $\mathrm{H}$, et al. Axin, a negative regulator of the Wnt signaling pathway, forms a complex with GSK-3beta and beta-catenin and promotes GSK-3beta-dependent phosphorylation of beta-catenin. EMBO J 1998;17:1371-1384.

19 Sakanaka C, Weiss JB, Williams LT. Bridging of beta-catenin and glycogen synthase kinase-3beta by axin and inhibition of beta-catenin-mediated transcription. Proc Natl Acad Sci USA 1998;95: 3020-3023.

20 Aberle H, Bauer A, Stappert J, et al. beta-catenin is a target for the ubiquitin-proteasome pathway. EMBO J 1997;16:3797-3804.

21 Jiang J, Struhl G. Regulation of the Hedgehog and Wingless signalling pathways by the F-box/WD40repeat protein Slimb. Nature 1998;391:493-496.

22 Orford K, Crockett C, Jensen JP, et al. Serine phosphorylation-regulated ubiquitination and degradation of beta-catenin. J Biol Chem 1997;272: 24735-24738.

23 Molenaar $M$, van de Wetering $M$, Oosterwegel $M$, et al. XTcf-3 transcription factor mediates betacatenin-induced axis formation in Xenopus embryos. Cell 1996;86:391-399.

24 Papkoff J, Rubinfeld B, Schryver B, et al. Wnt-1 regulates free pools of catenins and stabilizes APC-catenin complexes. Mol Cell Biol 1996;16: 2128-2134.

25 Porfiri E, Rubinfeld B, Albert I, et al. Induction of a beta-catenin-LEF-1 complex by wnt-1 and transforming mutants of beta-catenin. Oncogene 1997;15: 2833-2839.

26 Zhai Y, Wu R, Schwartz DR, et al. Role of betacatenin/T-cell factor-regulated genes in ovarian endometrioid adenocarcinomas. Am J Pathol 2002;160: 1229-1238.

27 Schwartz DR, Wu R, Kardia SL, et al. Novel candidate targets of beta-catenin/T-cell factor signaling identified by gene expression profiling of ovarian endometrioid adenocarcinomas. Cancer Res 2003;63: 2913-2922.

28 Hirohashi S. Inactivation of the E-cadherin-mediated cell adhesion system in human cancers. Am J Pathol 1998;153:333-339.

29 Mareel M, Boterberg T, Noe V, et al. E-cadherin/ catenin/cytoskeleton complex: a regulator of cancer invasion. J Cell Physiol 1997;173:271-274.

30 Becker KF, Atkinson MJ, Reich U, et al. E-cadherin gene mutations provide clues to diffuse type gastric carcinomas. Cancer Res 1994;54:3845-3852.

31 Berx G, Becker KF, Hofler H, et al. Mutations of the human E-cadherin (CDH1) gene. Hum Mutat 1998;12: 226-237.

32 Garinis GA, Menounos PG, Spanakis NE, et al. Hypermethylation-associated transcriptional silencing of E-cadherin in primary sporadic colorectal carcinomas. J Pathol 2002;198:442-449.

33 Matsumura T, Makino R, Mitamura K. Frequent downregulation of E-cadherin by genetic and epigenetic 
changes in the malignant progression of hepatocellular carcinomas. Clin Cancer Res 2001;7: 594-599.

34 Chen CL, Liu SS, Ip SM, et al. E-cadherin expression is silenced by DNA methylation in cervical cancer cell lines and tumours. Eur J Cancer 2003;39: 517-523.

35 Nieto MA. The snail superfamily of zinc-finger transcription factors. Nat Rev Mol Cell Biol 2002;3: 155-166.

36 Thiery JP. Epithelial-mesenchymal transitions in tumour progression. Nat Rev Cancer 2002;2:442-454.

37 Veltmaat JM, Orelio CC, Ward-Van Oostwaard D, et al. Snail is an immediate early target gene of parathyroid hormone related peptide signaling in parietal endoderm formation. Int J Dev Biol 2000;44: 297-307.

38 Cano A, Perez-Moreno MA, Rodrigo I, et al. The transcription factor snail controls epithelial-mesenchymal transitions by repressing E-cadherin expression. Nat Cell Biol 2000;2:76-83.

39 Batlle E, Sancho E, Franci C, et al. The transcription factor snail is a repressor of E-cadherin gene expression in epithelial tumour cells. Nat Cell Biol 2000;2: 84-89.

40 Cheng CW, Wu PE, Yu JC, et al. Mechanisms of inactivation of E-cadherin in breast carcinoma: modification of the two-hit hypothesis of tumor suppressor gene. Oncogene 2001;20:3814-3823.

41 Poser I, Dominguez D, de Herreros AG, et al. Loss of E-cadherin expression in melanoma cells involves up-regulation of the transcriptional repressor Snail. J Biol Chem 2001;276:24661-24666.

42 Yokoyama K, Kamata N, Hayashi E, et al. Reverse correlation of E-cadherin and snail expression in oral squamous cell carcinoma cells in vitro. Oral Oncol 2001;37:65-71.

43 Blanco MJ, Moreno-Bucno G, Sarrio D, et al. Correlation of Snail expression with histological grade and lymph node status in breast carcinomas. Oncogene 2002;21:3241-3246.

44 Rosivatz E, Becker I, Specht K, et al. Differential expression of the epithelial-mesenchymal transition regulators Snail, SIP1, and Twist in gastric cancer. Am J Pathol 2002;161:1881-1891.

45 Oda H, Tsukita S, Takeichi M. Dynamic behavior of the cadherin-based cell-cell adhesion system during Drosophila gastrulation. Dev Biol 1998;203: 435-450.

46 Carver EA, Jiang R, Lan Y, et al. The mouse snail gene encodes a key regulator of the epithelial-mesenchymal transition. Mol Cell Biol 2001;21:8184-8188.

47 Hemavathy K, Ashraf SI, Ip YT. Snail/slug family of repressors: slowly going into the fast lane of development and cancer. Gene 2000;257:1-12.

48 Hajra KM, Chen DY, Fearon ER. The SLUG zinc-finger protein represses E-cadherin in breast cancer. Cancer Res 2002;62:1613-1618.

49 Nieto MA, Sargent MG, Wilkinson DG, et al. Control of cell behavior during vertebrate development by Slug, a zinc finger gene. Science 1994;264: 835-839.

50 Carl TF, Dufton C, Hanken J, et al. Inhibition of neural crest migration in Xenopus using antisense slug RNA. Dev Biol 1999;213:101-115.

51 LaBonne C, Bronner-Fraser M. Snail-related transcriptional repressors are required in Xenopus for both the induction of the neural crest and its subsequent migration. Dev Biol 2000;221:195-205.

52 del Barrio MG, Nieto MA. Overexpression of Snail family members highlights their ability to promote chick neural crest formation. Development 2002;129: 1583-1593.

53 Comijn J, Berx G, Vermassen P, et al. The two-handed $\mathrm{E}$ box binding zinc finger protein SIP1 downregulates E-cadherin and induces invasion. Mol Cell 2001;7:1267-1278.

54 St Croix B, Sheehan C, Rak JW, et al. E-cadherindependent growth suppression is mediated by the cyclin-dependent kinase inhibitor p27(KIP1). J Cell Biol 1998;142:557-571.

55 Orsulic S, Huber $\mathrm{O}$, Aberle $\mathrm{H}$, et al. E-cadherin binding prevents beta-catenin nuclear localization and beta-catenin/LEF-1-mediated transactivation. J Cell Sci 1999;112(Part 8):1237-1245.

56 Gottardi CJ, Wong E, Gumbiner BM. E-cadherin suppresses cellular transformation by inhibiting beta-catenin signaling in an adhesion-independent manner. J Cell Biol 2001;153:1049-1060.

57 Handschuh G, Candidus S, Luber B, et al. Tumourassociated E-Cadherin mutations alter cellular morphology, decrease cellular adhesion and increase cellular motility. Oncogene 1999;18:4301-4312.

58 Ellison G, Klinowska T, Westwood RF, et al. Further evidence to support the melanocytic origin of MDAMB-435. Mol Pathol 2002;55:294-299.

59 Ihaka R, Gentleman R. A language for data analysis and graphics. J Comput Graph Statist 1996;5:299--314.

60 Little RJ, Rubin DB. Statistical Analysis with Missing Data. J Wiley: New York, 1987.

61 Cleveland WS. Robust locally weighted regression and smoothing scatterplots. J Amer Statist Assoc 1979;74:829-836.

62 Cleveland WS, Grosse E, Shyu WM. Local regression models. In: Chambers JM, Hasftie TJ (eds). Statistical Models in S. Florence. Wadsworth \& Brooks/Cole: KY, 1992.

63 Benjamini YO, Yekutieli DA. The Control of the False Discovery Rate in Multiple Testing under Dependency. Annals of Statistics 2001;29:1165-1188.

64 Becker KF, Kremmer E, Eulitz M, et al. Functional allelic loss detected at the protein level in archival human tumours using allele-specific E-cadherin monoclonal antibodies. J Pathol 2002;197: 567-574.

65 Luber B, Candidus S, Handschuh G, et al. Tumorderived mutated E-cadherin influences beta-catenin localization and increases susceptibility to actin cytoskeletal changes induced by pervanadate. Cell Adhes Commun 2000;7:391-408.

66 Demunter A, Libbrecht L, Degreef $\mathrm{H}$, et al. Loss of membranous expression of beta-catenin is associated with tumor progression in cutaneous melanoma and rarely caused by exon 3 mutations. Mod Pathol 2002;15:454-461.

67 Pollock PM, Hayward N. Mutations in exon 3 of the beta-catenin gene are rare in melanoma cell lines. Melanoma Res 2002;12:183-186.

68 Rubinfeld B, Robbins P, El-Gamil M, et al. Stabilization of beta-catenin by genetic defects in melanoma cell lines. Science 1997;275:1790-1792.

69 Leyns L, Bouwmeester T, Kim SH, et al. Frzb-1 is a secreted antagonist of Wnt signaling expressed in the Spemann organizer. Cell 1997;88:747-756. 
70 Wang S, Krinks M, Lin K, et al. Frzb, a secreted protein expressed in the Spemann organizer, binds and inhibits Wnt-8. Cell 1997;88:757-766.

$71 \mathrm{Xu}$ Q, D’Amore PA, Sokol SY. Functional and biochemical interactions of Wnts with FrzA, a secreted Wnt antagonist. Development 1998;125: 4767-4776.

72 Zhou Z, Wang J, Han X, et al. Up-regulation of human secreted frizzled homolog in apoptosis and its down-regulation in breast tumors. Int J Cancer 1998;78:95-99.

73 Ugolini F, Charafe-Jauffret E, Bardou VJ, et al. WNT pathway and mammary carcinogenesis: loss of expression of candidate tumor suppressor gene SFRP1 in most invasive carcinomas except of the medullary type. Oncogene 2001;20:5810-5817.

74 Nagafuchi A, Ishihara S, Tsukita S. The roles of catenins in the cadherin-mediated cell adhesion: functional analysis of E-cadherin-alpha catenin fusion molecules. J Cell Biol 1994;127:235-245.

75 McMahon AP, Moon RT. Ectopic expression of the proto-oncogene int-1 in Xenopus embryos leads to duplication of the embryonic axis. Cell 1989;58: 1075-1084.

76 Funayama N, Fagotto F, McCrea P, et al. Embryonic axis induction by the armadillo repeat domain of beta-catenin: evidence for intracellular signaling. J Cell Biol 1995;128:959-968.

77 Fagotto F, Funayama N, Gluck U, et al. Binding to cadherins antagonizes the signaling activity of betacatenin during axis formation in Xenopus. J Cell Biol 1996;132:1105-1114.

78 Heasman J, et al. Overexpression of cadherins and underexpression of beta-catenin inhibit dorsal mesoderm induction in early Xenopus embryos. Cell 1994;79:791-803.

79 Torres MA, et al. Activities of the Wnt-1 class of secreted signaling factors are antagonized by the Wnt-5A class and by a dominant negative cadherin in early Xenopus development. J Cell Biol 1996;133: 1123-1137.

80 Bafico A, Gazit A, Pramila T, et al. Interaction of frizzled related protein (FRP) with Wnt ligands and the frizzled receptor suggests alternative mechanisms for FRP inhibition of Wnt signaling. J Biol Chem 1999;274:16180-16187.

81 van de Wetering M, Barker N, Harkes IC, et al. Mutant E-cadherin breast cancer cells do not display constitutive Wnt signaling. Cancer Res 2001;61: 278-284.

82 Caca K, Kolligs FT, Ji X, et al. Beta- and gammacatenin mutations, but not E-cadherin inactivation, underlie T-cell factor/lymphoid enhancer factor transcriptional deregulation in gastric and pancreatic cancer. Cell Growth Differ 1999;10:369-376.

83 Labbe E, Letamendia A, Attisano L. Association of Smads with lymphoid enhancer binding factor $1 / \mathrm{T}$ cell-specific factor mediates cooperative signaling by the transforming growth factor-beta and wnt pathways. Proc Natl Acad Sci USA 2000;97: 8358-8363.

84 Zawel L, Dai JL, Buckhaults P, et al. Human Smad3 and Smad4 are sequence-specific transcription activators. Mol Cell 1998;1:611-617.
85 Behrens J, Mareel MM, Van Roy FM, et al. Dissecting tumor cell invasion: epithelial cells acquire invasive properties after the loss of uvomorulinmediated cell-cell adhesion. J Cell Biol 1989;108: 2435-2447.

86 Frixen UH, Behrens J, Sachs $\mathrm{M}$, et al. E-cadherinmediated cell-cell adhesion prevents invasiveness of human carcinoma cells. J Cell Biol 1991;113: 173-185

87 Perl AK, Wilgenbus P, Dahl U, et al. A causal role for E-cadherin in the transition from adenoma to carcinoma. Nature 1998;392:190-193.

88 Vleminckx K, Vakaet Jr L, Mareel M, et al. Genetic manipulation of E-cadherin expression by epithelial tumor cells reveals an invasion suppressor role. Cell 1991;66:107-119.

89 Chen WC, Obrink B. Cell-cell contacts mediated by E-cadherin (uvomorulin) restrict invasive behavior of L-cells. J Cell Biol 1991;114:319-327.

90 Navarro P, Gomez M, Pizarro A, et al. A role for the E-cadherin cell-cell adhesion molecule during tumor progression of mouse epidermal carcinogenesis. J Cell Biol 1991;115:517-533.

91 Christofori G, Semb H. The role of the cell-adhesion molecule E-cadherin as a tumour-suppressor gene. Trends Biochem Sci 1999;24:73-76.

92 Hennig G, Lowrick O, Birchmeier W, et al. Mechanisms identified in the transcriptional control of epithelial gene expression. J Biol Chem 1996;271: 595-602.

93 Giroldi LA, Bringuier PP, de Weijert M, et al. Role of E boxes in the repression of E-cadherin expression. Biochem Biophys Res Commun 1997;241:453-458.

94 Faraldo ML, Rodrigo I, Behrens J, et al. Analysis of the E-cadherin and P-cadherin promoters in murine keratinocyte cell lines from different stages of mouse skin carcinogenesis. Mol Carcinog 1997;20: $33-47$.

95 Hajra KM, Ji X, Fearon ER. Extinction of E-cadherin expression in breast cancer via a dominant repression pathway acting on proximal promoter elements. Oncogene 1999;18:7274-7279.

96 Rodrigo I, Cato AC, Cano A. Regulation of E-cadherin gene expression during tumor progression: the role of a new Ets-binding site and the E-pal element. Exp Cell Res 1999;248:358-371.

97 Grooteclaes ML, Frisch SM. Evidence for a function of CtBP in epithelial gene regulation and anoikis. Oncogene 2000;19:3823-3828.

98 Polyak K, Kato JY, Solomon MJ, et al. p27Kip1, a cyclin-Cdk inhibitor, links transforming growth factor-beta and contact inhibition to cell cycle arrest. Genes Dev 1994;8:9-22.

99 Behrens J, Frixen U, Schipper J, et al. Cell adhesion in invasion and metastasis. Semin Cell Biol 1992;3:169-178.

100 Stetler-Stevenson WG, Aznavoorian S, Liotta LA. Tumor cell interactions with the extracellular matrix during invasion and metastasis. Annu Rev Cell Biol 1993;9:541-573.

101 Bolos V, Peinado H, Perez-Moreno MA, et al. The transcription factor Slug represses E-cadherin expression and induces epithelial to mesenchymal transitions: a comparison with Snail and E47 repressors. J Cell Sci 2003;116(Part 3):499-511. 